many fields and the results of our labours have doubtless gone by now to the pulping machine for salvage. We would put in a word in favour of the Priestley Smith model. It was and is an admirable perimeter and especially handy in mapping the dividing line in cases of hemianopia if one clipped the test object on the arc and worked from the blind to the seeing side. We have not very much to say in favour of the confrontation method, but it is useful as a rough guide for major field defects. If any such are found by this method the field should always be charted on a perimeter. It has been our experience on more than one occasion to hear a patient say, "but .Mr. so and so did not examine my eyes with this instrument." Even if the field examination' yields no assistance to the diagnosis it sometimes impresses the patient, though perhaps this is adopting a low standard of ophthalmological morality. It will be found useful we think to take visual fields as a routine in examining very aged persons. Their media are frequently far from clear and one may get useful help especially in doubtful cases. The examination of the central parts of the field for scotomata is not included under this heading; it very often yields much more information than a chart of the peripheral field; but it takes time and experience to get consistently satisfactory, results.

\title{
COUNCIL OF BRITISH OPHTHALMOLOGISTS
}

\section{Plan for Formation of a Faculty of Ophthalmologists}

THERE is obvious need for an authoritative and representative body to guide ophthalmologists through the intricate and important problems which are to be settled in the near future, to represent their interests to the State, and to co-ordinate their efforts, so that in the coming re-orientation of the medical service of the country the greatest good accrues to the people, while at the same time the interests of the profession are preserved. It is generally accepted that, although circumstances may necessitate that changes be gradual, fundamental principles are now being evolved which will profoundly affect the medical profession and the community at large. So far as the ophthalmic services are concerned, the alternative to having policies imposed by others is to establish an authoritative body which will be able to initiate and criticise policy so that the interests both of the profession and the community may be furthered.

The need for a body of this sort became apparent towards the end of the last war, and on the initiative of certain leading ophthalmic surgeons a general meeting of British ophthalmologists 
was held on May 2, 1918, at which it was decided to establish a Council of British Ophthalmologists, consisting of the Presidents and Past Presidents of the Ophthalmological Society of the United Kingdom and the Section of Ophthalmology of the Royal Society of Medicine, together with nine members elected annually, four each by the Councils of these bodies and one by the Council of the Oxford Congress. Later the Master and the Past Masters of the Oxford Congress were added as permanent members and the number of elected members increased.

The functions of the Council, as stated in its rules, were "To take cognisance of, and to act in all matters of ophthalmic interest arising in connection with national industries and public services, and to initiate or to advise concerning movements which have for their objects the welfare of the eyesight of the community."

The Council of British Ophthalmologists has done much valuable work in many different fields-political, educational, and scientific ; but recently it has been felt that this Council would have more weight and authority if it were more directly representative of the whole body of ophthalmologists in the country.

Some of the immediate problems which require examination and early solution are of great moment. The White Paper outlining the Government's proposals for a National Health Service deals vaguely with an ophthalmic service, although it is clear that it is the Government's intention to establish such a service. It will be the first task of the Faculty to examine the many questions arising in this connection, and its aim, in collaboration with the appropriate Ministries and other bodies concerned, to play an important part in determining the form which this service will take. This raises questions not only of conditions of service, but of the relation of the ophthalmic practitioner to the dispensing and sight-testing opticians, the methods of spectacle supply, the establishment and control of clinics, and so on, all of which are of far-reaching importançe. Moreover, the institution of a National Service will raise the issue of the personnel who are to be considered as ophthalmologists, and the regionalisation of Hospital Services will require adequate planning.

In addition to these medico-political matters it is evident that the question of education and research, clinic and hospital policy, industrial problems, and a host of others are to assume importance in the immediate future. It is advisable that the whole body of ophthalmologists should play a part in the institution of such policies as they affect their specialty and be in possession of a mechanism to influence their development. Organisations apart from ophthalmologists are taking an interest in such questions. It would seem of importance that there should be scme body more representative than the Council of British Ophthalmologists, as at present constituted, to guide the profession and advise the State. 
The Council of British Ophthalmologists have therefore decided to promote the formation of a Faculty of Ophthalmologists.

The functions of the Faculty will be:-

1. To take cognisance of, and to act in, any matters of ophthalmic interest.

2. To encourage suitable standards of education in ophthalmology for undergraduate and postgraduate students.

3. To encourage research in ophthalmology and cognate subjects.

4. To secure such conditions in ophthalmic practice as will attract persons of high professional attainments and afford ample scope for the exercise of their abilities.

5. To maintain a high ethical standard in ophthalmic practice.

6. To act as an authoritative body for the purpose of consultation in matters of public and professional ophthalmic interest.

\section{Constitution of Faculty}

The Faculty shall consist of Members and Associates who must be registered Medical practitioners and have the following qualifications :-

\section{Members}

Only ophthalmologists of full consultant status shall be eligible for membership. They shall be :-

1. Ophthalmic surgeons to hospitals recognised as schools of ophthalmology by universities or other medical examining bodies.

2. Ophthalmic surgeons other than the above who have been engaged for at least five years in full-time practice as specialists. and have charge of bedś in voluntary hospitals approved by the Council (at the initiation of the scheme, approved by the C.B.O.). Provisionally, these shall be general hospitals of more than 200 beds and special ophthalmic hospitals of more than 20 beds.

3. Persons no longer on the active staffs of hospitals who have held appointments specified in Classes (1) and (2).

4. Other ophthalmic surgeons of consultant rank approved by the Council, including those in the Services or holding Government appointments.

\section{Associates}

Any ophthalmologist who has been for at least two years in fulltime practice as a specialist (civilian or Service) shall be eligible for election as an Associate, on application in prescribed form and approval by the Council.

Note.-The above qualifications for Members and Associates are possibly temporary standards which may require revision in case of the establishment of a national grading of consultants and specialists. 


\section{Executive Organisation}

Executive powers shall be vested in a Council which, for the sake of continuity, shall be known as the Council of British Ophthalmologists. This Council shall consist of 21 members, of whom 15 shall be elected by Members and 6 by Associates of the Faculty.

\section{Officers}

The Officers of the Faculty shall be the President, Vice-President, Hon. Secretary and Hon. Treasurer who shall be elected annually by the Council from among its members.

Election to the Council shall be by postal ballot on a national basis, but with provision as follows for regional representation. The electorate-will be divided into five regions. In the case of Members, the candidate in each region who receives the highest number of votes in the national ballot shall be deemed elected as. the representative of his particular region. Thereafter the remaining seats on the Council shall be filled by those other candidates receiving the highest numbers of votes in the national ballot. In the case of Associates, the candidate in each region receiving the largest number of votes in the national ballet will be deemed elected, except in the London region where the two candidates receiving the highest number of votes will be deemed elected: As there will be five regions all the six seats open to Associate candidates will thus be filled.

One third of the members of the Council shall retire each year. The members of the Council to retire in every year shall be those who have been longest in office, but as between persons who became members of the Council on the same day, those to retire shall be determined by the Council by such method as it shall think fit.

Members of the Council shall be eligible for re-election for a further period of three years, but after the second period of three years shall be eligible only after a lapse of one year.

The Council shall call an annual general meeting of the Faculty to receive and discuss its report. Any Member or Associate of the Faculty shall have the right to bring up for discussion at the annual meeting, after giving due notice to the Secretary, any subject within the province of the Faculty.

The Council shall have the power to call a special general meeting of the Faculty at any time in case of need.

Standing Committees. The Council shall appoint standing committees to deal with certain branches of its work. These committees shall have no independent executive power,. Their function shall be to advise the Council on the subjects with which they deal. Any Member or Associate of the Faculty may be appointed to serve on them, but the chairman of every standing 
committee shall be a member of the Council. Persons not Members or Associates may be co-opted for temporary service on standing committees when required.

The same rules shall apply with regard to period of service on a standing committee as in the case of the Council,'

Special Committees. The Council shall have power to appoint special committees to deal with special subjects and report thereon to the Council. Persons' who are not Members or Associates of the Faculty may be invited to serve on special committees, and these committees may be given power to co-opt such persons.

\section{Subscriptions}

Members of the Faculty shall pay an initial subscription of three guineas and Associates one of one guinea. The subsequent subscription shall be determined by the Council.

It is anticipated that the new Faculty will work in co-operation with the Universities, Royal Colleges and Corporations of Great Britain and Northern Ireland, and maintain a close liaison with the Ophthalmic Group Committee of the British Medical Association.

The Council of British Ophthalmologists has appointed a special committee to organise the Faculty, to enrol Members and Associates, and to make the necessary arrangements as soon as possible for the election of the Council. When the new Council hàs been established it will assume all the functions of the present Council of British Ophthalmologists, which will hand over all its records and any other property in its possession.'

Forms of application for enrolment as Members or Associates may be obtained from the Hon. Secretary of the organising committee :-

$$
\begin{aligned}
& \text { Mr. Frank W. LAw, } \\
& \text { 45, Lincoln's Inn Fields, } \\
& \text { London, W.C. } 2
\end{aligned}
$$

\section{ABSTRACTS}

\section{MISCELLANEOUS}

(1) Glover, L. P. and Brewer, W. R. (Altoona, Pennsylvania).An ophthalmologic review of more than twenty thousand men at the Altoona Induction Centre. Amer. Jl. Ophthal,, Vol. XXVII, p. 346, 1944.

(1) Glover and Brewer give a statistical table of the incidence of refractive errors, congenital defects, injuries and ocular diseases 